\title{
How Do Pathogens Evolve Novel Virulence Activities?
}

\author{
Soledad Sacristán, ${ }^{1,2, \dagger}$ Erica M. Goss, ${ }^{3}$ and Sebastian Eves-van den Akker ${ }^{4, \dagger}$ \\ ${ }^{1}$ Centro de Biotecnología y Genómica de Plantas, Universidad Politécnica de Madrid (UPM)-Instituto Nacional de \\ Investigación y Tecnología Agraria y Alimentaria (INIA), Campus Montegancedo-UPM, 28223-Pozuelo de Alarcón (Madrid), \\ Spain \\ ${ }^{2}$ Departamento de Biotecnología-Biología Vegetal, Escuela Técnica Superior de Ingeniería Agronómica, Alimentaria y de \\ Biosistemas, Universidad Politécnica de Madrid, 28040-Madrid, Spain \\ ${ }^{3}$ Department of Plant Pathology and Emerging Pathogens Institute, University of Florida, Gainesville, Florida, U.S.A. \\ ${ }^{4}$ Department of Plant Sciences, University of Cambridge, Cambridge CB1 2EA, U.K.
}

Accepted 28 January 2021.

\begin{abstract}
We consider the state of knowledge on pathogen evolution of novel virulence activities, broadly defined as anything that increases pathogen fitness with the consequence of causing disease in either the qualitative or quantitative senses, including adaptation of pathogens to host immunity and physiology, host species, genotypes, or tissues, or the environment. The evolution of novel virulence activities as an adaptive trait is based on the selection exerted by hosts on variants that have been generated de novo or arrived from elsewhere. In addition, the biotic and abiotic environment a pathogen experiences beyond the host may influence pathogen virulence activities. We consider host-pathogen evolution, host range expansion, and external factors that can mediate pathogen evolution. We then discuss the mechanisms by which pathogens generate and recombine the genetic variation that leads to novel virulence activities, including DNA point mutation, transposable element activity, gene duplication and neofunctionalization, and genetic exchange. In summary, if there is an (epi)genetic mechanism that can create variation in the genome, it will be used by pathogens to evolve virulence factors. Our knowledge of virulence evolution has been biased by pathogen evolution in response to major gene resistance, leaving other virulence activities underexplored. Understanding the key driving forces that give rise to novel virulence activities and the integration of evolutionary concepts and methods with mechanistic research on plant-microbe interactions can help inform crop protection.
\end{abstract}

${ }^{\dagger}$ Corresponding authors: S. Sacristán; soledad.sacristan@upm.es and S. Eves-van den Akker; se389@cam.ac.uk

Funding: S. Sacristán was supported through a Spanish Research Agency grant RTI2018-096975-B-I00, E. M. Goss through National Institute of Food and Agriculture grants 2015-51181-24312, 201767013-26870, and 2019-51181-30010, as part of the joint United States Department of Agriculture National Science Foundation National Institutes of Health Ecology and Evolution of Infectious Diseases program, and S. Eves-van den Akker through Biotechnology and Biological Sciences Research Council grants BB/R011311/1, and BB/S006397/1.

The author(s) declare no conflict of interest.

(c) (1) (9) Copyright (ㅇ 2021 The Author(s). This is an open access article distributed under the CC BY-NC-ND 4.0 International license.
Keywords: effector, gene duplication, horizontal gene transfer, host range, mutation, pathogenicity, recombination, resistance, selection

When the International Society for Molecular Plant-Microbe Interactions (MPMI) community voted on the Top 10 questions in MPMI in 2019, the ninth ranked question was How do pathogens evolve novel virulence activities? (Harris et al. 2020). Virulence is fundamental to plant-pathogen interactions, and the study of mechanisms of virulence is a central research theme in the MPMI community. The evolution of novel virulence activities is also critical to the application of foundational MPMI research because pathogen evolution often triggers the emergence and re-emergence of economically and ecologically damaging plant diseases. This review comes at a time when we have access to affordable and portable genome or transcriptome sequencing (or both) for any pathogen. Thus, we are on the cusp of feasibly exploring this question across many pathosystems and, potentially, in near-real time. The era of big data and new innovations in artificial intelligence will also contribute to new understanding of known virulence mechanisms and will likely reveal novel virulence activities. In this review, we consider how far we have come in answering this question, some compelling open unknowns, and directions for future research.

\section{WHAT ARE VIRULENCE ACTIVITIES AND HOW DO THEY EVOLVE?}

What is virulence? There has been confusion around the term virulence among plant pathologists since van der Plank (1968) used it to describe the capacity of a pathogen to infect a particular host genotype, while in animal pathology and evolutionary biology virulence is usually related to the harm that infection causes to the host (Sacristán and García-Arenal 2008). The American Phytopathological Society (D'Arcy et al. 2001) adopted the conventions of using pathogenicity as a qualitative description of the ability of a pathogen to cause disease (similar to van der Planck) and virulence as a quantitative measure of the degree of pathogenicity (similar to the meaning of virulence in other disciplines). Causing disease is a definitive property of pathogens, and it is frequently assumed to be a consequence of pathogen fitness. In this review, we consider virulence activities to be anything that enables pathogens to infect and multiply (i.e., increase pathogen fitness) with the 
consequence of causing disease in either the qualitative or quantitative senses (Fig. 1). Therefore, novel virulence activities can include the adaptation of pathogens to i) host immunity and physiology, ii) host species, genotypes, or tissues, iii) the environment, and iv) may include production of more efficient reproductive structures or competing or cooperating better with other microorganisms in the ecosystem (Fig. 1). These novel virulence activities may evolve by acquisition or adaptation of virulence factors (i.e., genes that contribute to the ability of a pathogen to infect and multiply within the host) or virulencerelated factors (i.e., genes indirectly involved in virulence activities). The evolution of novel virulence activities as an adaptive trait is based on the selection exerted on variants that have been generated de novo or arrived from elsewhere. In this review, we will first address the selective factors that affect virulence activities and, then, the mechanisms that generate diversity in pathogen populations.

\section{SELECTIVE FACTORS FOR VIRULENCE ACTIVITIES}

Pathogen fitness relies on the ability to multiply in a host and transmit to other hosts. Therefore, the host is certainly the main driver for the evolution of virulence activities. Pathogen virulence activities are continually evolving to retain the ability to infect and multiply in the host, which, in turn, evolves new ways (or is bred) to detect and combat pathogen attack. Moreover, novel virulence activities may allow the pathogen to acquire new hosts, expanding its host range, or change host specificity leading to host jumps. Besides the host, environmental factors a pathogen experiences during its life cycle may influence the direction of evolution and thus lead to new virulence activities. Nonhost factors may be abiotic and biotic. They can condition the capacity of the pathogen to survive outside the host and transmit to other hosts and can also modulate the ability of the pathogen to interact with the host.

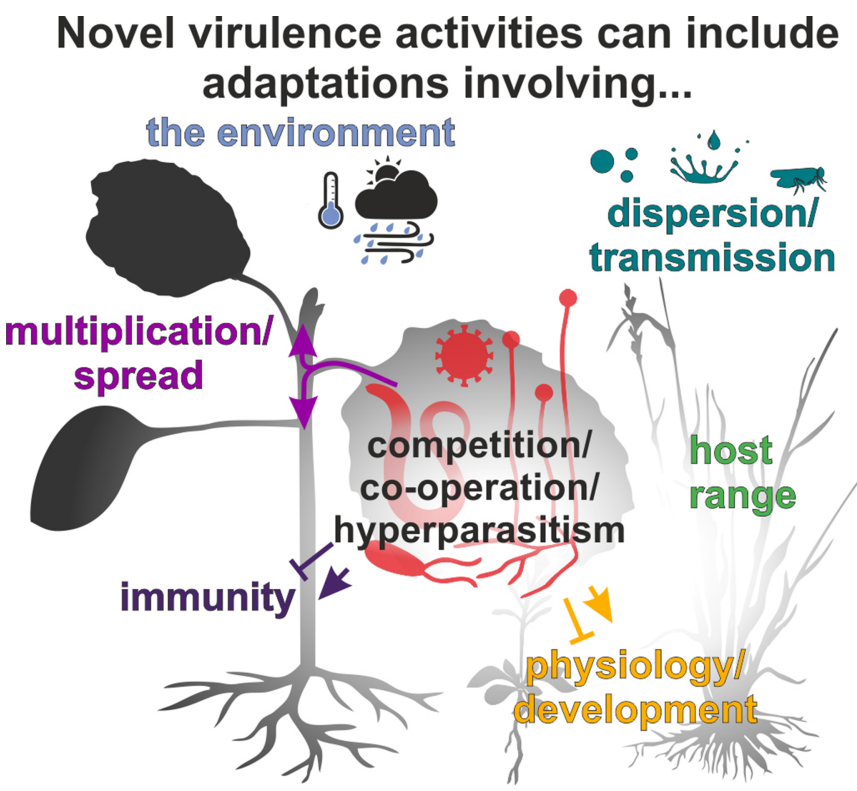

Fig. 1. A spectrum of novel virulence activities. Novel virulence activities can include adaptations that alter how pathogens interact with the host immune system (dark purple) or with host physiology and development (orange), the ability to multiply and spread within the host (light purple), how they disperse and are transmitted to other hosts (turquoise), their host range (including host expansions and host jumps, green), how they interact with the environment (blue), and how they interact with other pathogenic and nonpathogenic microorganisms (red).
Host-pathogen coevolution: the gene-for-gene interaction and beyond.

Plants impose physical and biological barriers that pathogens must breach to infect and multiply. For example, plants recognize microbe-associated molecular patterns and trigger immune responses that pathogens must overcome by the use of effectors, secreted proteins or other molecules that contribute to pathogen fitness in the host (Jones and Dangl 2006). A plant resistance $(R)$ gene may recognize an effector (termed then an avirulence $[a v r]$ gene), often on a gene-for-gene basis, and trigger localized cell death, thereby blocking the in-planta spread of the pathogen. In such a case, resistance is dominant and the host selects for pathogen alleles that avoid this response, including 'loss-offunction' (Dodds and Rathjen 2010). It should be emphasized that, in this context, loss-of-function mutations in avr genes refers to alleles that evade immune receptors, although they may maintain their virulence function. Novel virulence activities can also be 'gain-of-function' events, for example, another effector that subverts this response or alters plant physiology in some other way that benefits the pathogen. Plants, in turn, can evolve novel $R$ gene specificities in a coevolutionary process that can be tracked by patterns of variation generated by diversifying or balancing selection in pathogen and plant genomes (Van der Hoorn et al. 2002). Screening genomes for signatures of selection has revealed previously unidentified effectors (de Vries et al. 2020), and population studies of gene or allele frequencies have uncovered virulence factors with important but quantitative effects (Abrahamian et al. 2018; Cooke et al. 2012). The genefor-gene model of interaction (Jones 2019) has greatly contributed to the understanding of the evolution of pathogenicity of biotrophs and hemibiotrophs (McDonald and Solomon 2018). Maintenance of allelic variation under this model assumes a cost of virulence activities in the absence of selection, although the impact of the costs and how to measure them are not yet fully resolved (Brown and Tellier 2011; Milgroom 2015).

Beyond suppressing the plant immune system, pathogens manipulate plant biology for their growth and transmission. For example, hemi- and biotrophic pathogens may deliver effectors to alter the function of non-immunity related host genes (so called S genes [Cox et al. 2017]). In Potyvirus and Sobemovirus species, the virus-encoded protein covalently linked to the $5^{\prime}$ terminus of the genomic RNA ( $\mathrm{VPg}$ ) must interact correctly with host eukaryotic translation initiation factor (eIF) (Hébrard et al. 2010; Robaglia and Caranta 2006). Resistance is attained by recessive alleles of the host target that are not recognized by the pathogen virulence factors. In this case, host-pathogen coevolution follows the matching-allele or inverted gene-for-gene model, in which different variants in pathogen virulence factors evolve to match the corresponding host alleles (Sacristán and García-Arenal 2008). This model is also applicable to the evolution of some necrotrophic pathogens, whereby cell death favors the pathogen and is stimulated either by triggering $R$ gene-mediated reactions or by the gain-of-function of a secreted toxin (Stukenbrock and McDonald 2009).

There are, thus, two main drivers of effector evolution, evasion of host immunity and adaptation to newly evolved or existing host factors. While much of our knowledge has been directed to understanding the former, there is still much to unveil about the latter. Also, while gene-for-gene and matching-allele interactions are reasonably numerous and well-characterized because they are relatively simple, increasing evidence points to interactions being more complex than previously described (Petit-Houdenot and Fudal 2017). Furthermore, the precise function of effectors and their host targets are still unknown in many cases (Büttner 2016; Camborde et al. 2019; Li and Day 2019; Lo Presti et al. 2015). It is also not clear the extent to which nonproteinaceous molecules (nucleic acids, pathogen-derived small molecules, metabolites, 
and lipids) contribute to virulence activities and whether they are encompassed by these evolutionary models (Frantzeskakis et al. 2020; Leisner and Schoelz 2018).

\section{The infection cycle and its trade-offs.}

Most knowledge about the pathogen interaction with the plant is based on the first steps that lead to infection and have the relatively simple models of single gene interactions explained above. However, the process of pathogen multiplication in the host is complex and the host may exert selection for different pathogen alleles or combinations thereof at various stages of infection, growth, replication, and transmission. For example, comparison of different strains of the oat crown rust fungus on different varieties of its host revealed that both pathogen and host genotype significantly affected total spore production, with pathogen genotype having the strongest effect on the early stage of infection efficiency and host genotype most strongly affecting the later life-history stages of the latent period and sporulation capacity (Bruns et al. 2012). The virulence activities across a pathogen life cycle, far from being independent of each other, are frequently interconnected. There are several examples that show the links between virulence factors that promote pathogen growth within the plant and its transmission to other hosts. Pth effectors in the citrus canker pathogen Xanthomonas citri cause rapid growth of the bacteria upon infection and are responsible for producing pustules that facilitate transmission by wind and rain (Brunings and Gabriel 2003; Graham et al. 2004). In Xylella fastidiosa, biofilm formation increases virulence by restricting water flow in the xylem and is also required for insect transmission (Killiny et al. 2013). Virulence activities may also be a byproduct of selection for pathogen survival outside of its host or hosts (e.g., biofilm and toxin production [Morris et al. 2009; Kettles et al. 2018]) or a combination of factors. For example, melanin protects fungi from environmental stress and is also required for appressoria to penetrate the host in some pathogenic fungi (Henson et al. 1999), while the transcription factor Amr1, which induces melanin biosynthesis in Alternaria brassicicola, negatively affects virulence (Cho et al. 2012). Thus, the complex relationships among traits affecting different stages in the infection cycle may result in trade-offs between virulence activities and these can vary among pathogen genotypes and ecological/ host contexts (Bruns et al. 2012; Kirchner and Roy 2000; Meyer et al. 2010; Pariaud et al. 2009).

One of the most generally assumed of such trade-offs is that between pathogen virulence and transmission (Anderson and May 1982; Ewald 1983). Examples above illustrate how pathogens may need to attain a within-host multiplication level that allows successful transmission but abundant multiplication can cause so much host harm that it limits available time for transmission. Therefore, models of virulence evolution predict an optimal virulence level that maximizes pathogen growth and transmission (Anderson and May 1982; Ewald 1983). Thus, the tradeoffs in virulence activities within and outside the host may result in virulence (i.e., host harm) not being maximized when pathogen fitness is maximized (Alizon et al. 2009). In an extreme case, virulence is reduced in pathogens that are vertically transmitted through the seed to allow the plant to complete the reproductive cycle. Cucumber mosaic virus virulence was significantly reduced after five generations of vertical transmission through seeds in a serial-passage experiment in Arabidopsis thaliana, whereas virulence did not change in viruses transmitted horizontally by mechanical transmission (Cobos et al. 2019; Pagán et al. 2014). Some fungal endophytes of the genera Epichlö and Neotyphodium that lack sexual reproduction transmit mostly vertically through seed without any harm to the plant, in contrast with sexually reproducing strains that castrate plant flowers with their reproductive structures (Schardl 1996).
Adaptation to different hosts may also impose trade offs in the evolution of virulence activities (Bera et al. 2018; Dutta et al. 2021; Huang et al. 2019; Sacristán et al. 2005). It is assumed that the ability of generalist pathogens to exploit multiple different hosts entails costs, and host specialization may result in more fecund pathogen phenotypes (Barrett and Heil 2012; Elena et al. 2014). Thus, trade-offs in the adaptation to different hosts may force generalist pathogens toward host specialization, and it is generally assumed that this is the fate of host-pathogen coevolution (Brown and Tellier 2011; Burdon and Thrall 2009). However, the molecular mechanisms associated with adaptive evolution of host-specific lineages of a multihost plant pathogen remain mostly poorly understood (Bedhomme et al. 2015). Trade-offs between virulence and transmission or in the breadth of host adaptation may have consequences in the severity of diseases in agroecosystems (McDonald and Stukenbrock 2016; Milgroom 2015). Agricultural conditions may increase the probabilities of between-host transmission and host specialization because of large, dense, and genetically uniform monocultures, favoring pathogens that reproduce quickly and, thus, selecting for higher virulence. However, experimental data about tradeoffs in the evolution of virulence activities are often contradictory (Remold 2012; Sacristán and García-Arenal 2008). Also, there is little known about the molecular mechanisms that hold back pathogen virulence (Sanfaçon 2020; Tanaka et al. 2006).

\section{Adaptation to new hosts.}

One of the most relevant consequences of novel virulence activities is the ability to infect new hosts, which ultimately leads to the emergence of new diseases (McLeish et al. 2017; Woolhouse and Gowtage-Sequeria 2005). We have some knowledge about the mechanisms for overcoming the defenses and exploiting host resources by pathogens, but we still do not know the key mechanisms that lead to the adaptation to a new host and, thus, determine pathogen host range (Jones 2009; Morris and Moury 2019). Pathogen host range may vary from one or very few to several hundred different plant species (specialists versus generalists pathogens), although this may be difficult to determine, depending on the definitions of host and adaptation to host (Morris and Moury 2019; Sacristán and García-Arenal 2008). Determinants of host range may be both intrinsic (availability of virulence factors that allow the interaction with different hosts) and extrinsic (e.g., exposure of plants to microorganisms and environmental conditions favorable for infection) (McLeish et al. 2017; Morris and Moury 2019). Extrinsic determinants include ecological factors, such as host population structure and diversity, epidemiological, such as vector availability and dynamics, or even stochastic events (Brown and Tellier 2011; McLeish et al. 2018). Host range evolution has mostly been studied by focusing on the intrinsic, genetic factors, but studies on the role of extrinsic factors are starting to gain importance (McLeish et al. 2017).

Adaptation of pathogens to new hosts may lead to host range expansions and host jumps, the latter when the ability to infect a new host leads to genetic differentiation of pathogen populations on different hosts and, finally, pathogen speciation (Thines 2019). It is broadly observed that pathogens tend to infect plants that are closely related, rendering the phylogenetic distance between plant taxa as an important predictor of the risk of a new host acquisition (Gilbert et al. 2012; Schulze-Lefert and Panstruga 2011). However, there are also many examples of related plant pathogens that are able to infect distant hosts, so other factors such as host geographical, ecological, or physiological distance may play a role (McLeish et al. 2017; Morris and Moury 2019; Thines 2019). This is the case of new host acquisitions by indigenous pathogens when a host is introduced in a new area, such as the case of Cocoa swollen shoot virus, which was a pathogen of the native forest tree Cola chlamydantha before 
cocoa was introduced in West Africa (Thresh 1982). Also important is the role of bridge hosts in facilitating host jumps and range expansions. For example, widespread deployment of rwt3 wheat in Brazil followed by the loss of function of PWT3 is proposed to be at the origin of the host jump to common wheat of Lolium pathotypes of Magnaporthe oryzae (Inoue et al. 2017).

The first step in the ability to infect a new host should be overcoming so-called nonhost resistance (i.e., resistance shown by an entire plant species against all known genetic variants [or isolates] of a specific parasite or pathogen [Antonovics et al. 2013]). This type of broad and durable resistance is one of the most aspired aims in crop protection, and, indeed, MPMI Top 10 question 6 is about its molecular basis (Harris et al. 2020; Panstruga and Moscou 2020). Since nonhost resistance is mechanistically indistinguishable from other types of plant immunity, virulence factors for the adaptation to new hosts may not be very different from those deployed against host resistance (Panstruga and Moscou 2020). Indeed, there is convincing evidence pointing to the role of effectors in shaping host range and leading to new host acquisitions both by gain or loss of functions (Frantzeskakis et al. 2020; Li et al. 2020a; Morris and Moury 2019). However, nonhost resistance may be one of several hurdles that microorganisms need to overcome to infect and cause disease in a new host, so mechanisms to acquire novel host virulence activities should frequently be more complicated than just acquiring one or a few virulence factors (Morris and Moury 2019; Thordal-Christensen 2003). For example, Fusarium oxysporum f. sp. radicis-cucumerinum causes disease in cucurbits, whereas $F$. oxysporum f. sp. melonis (Fom) is limited to melon. $\mathrm{Li}$ et al. (2020b) found that $F$. oxysporum f. sp. melonis can colonize root xylem of other cucurbits but cannot reach the stem like F. oxysporum f. sp. radicis-cucumerinum. A roughly $300-\mathrm{kb}$ region in a pathogenicity chromosome appears to be responsible for this ability to colonize the stem of cucurbits. In phytopathogenic bacteria, such as Pseudomonas and Xanthomonas spp., host jumps are associated with acquisition of new genes and alleles but generally require more than the transfer of single effectors (Dillon et al. 2019; Timilsina et al. 2020). Which genes are important and why and why some effectors make a relatively greater contribution to overcome nonhost resistance and exploit a new host are open questions.

\section{Selection beyond the host.}

Abiotic and biotic factors other than the host also affect pathogen virulence activities and thereby fitness (Morris and Moury 2019). Temperature, for example, is a key driver of ecological specialization of pathogens (Chaloner et al. 2020) and can entail trade-offs with components of pathogen fitness (Chen et al. 2017; Yang et al. 2018). Ecological complexity also affects evolutionary trajectories of pathogens, and more research using multihost and multipathogen systems is needed to understand the consequences for virulence activities (McLeish et al. 2017). Next-generation sequencing studies have revealed the enormous diversity of microorganisms that coexist within a plant, showing that coinfection is the rule rather than the exception and highlighting the relevance of microbe-microbe interactions in the phytobiome (Hassani et al. 2018; Snelders et al. 2018; Teixeira et al. 2019). Indeed, plant pathogens do not exist or infect in isolation; they are consumed by animals, are hosts to other pathogens and parasites, and may cooperate (Wheeler et al. 2019) or compete (Snelders et al. 2018) with the many other microbes in their hosts (Tollenaere et al. 2016). These synergistic or antagonistic interactions can increase or decrease disease severity (Mascia and Gallitelli 2016). For example, Rhizoctonia solani AG 2-2IIIB hosts an Enterobacter sp. that is required for virulence and toxin production on turfgrass (Obasa et al. 2017), while Cryphonectria parasitica shows hypovirulence when infected by a mycovirus (Choi and Nuss 1992). Complex biotic interactions may also confuse identification of the 'causal' agent (Wheeler et al. 2019). Both biotic and abiotic factors are of considerable importance to understanding pathogen evolution and disease emergence in light of climate change, globalization, and other anthropogenic habitat modifications (Bebber 2015; Velásquez et al. 2018). Other Top 10 questions in MPMI, i.e., How does abiotic stress, such as climate change, influence plantmicrobe interactions? (question 2), How do microbe-microbe interactions affect plant-microbe interactions? (question 4), and How do observations of binary plant-microbe interactions hold in an ecological context? (question 10), bring forth these important points (Harris et al. 2020).

\section{GENETIC MECHANISMS UNDERPINNING THE EVOLUTION OF NOVEL VIRULENCE ACTIVITIES}

Selection acts on genetic variation. The ultimate source of epigenetic and genetic variation is DNA mutation that generates novel coding sequences or changes gene regulation. Sexual or asexual genetic exchange between closely or distantly related individuals shuffles genetic variation, resulting in further novel phenotypes. This section reviews the various mechanisms by which pathogens generate and recombine variants and the virulence activities that result.

\section{Mutation and mutation rate bias.}

Mutation is defined as any heritable change in the genome of an organism that can occur at the level of one or a few nucleotides up to larger scales of genes or segments of chromosomes. Depending on the mechanism of pathogenesis and host resistance, a single nucleotide mutation can give rise to a virulent pathogen genotype (Bartoli et al. 2016; Grandaubert et al. 2019; Pagán and García-Arenal 2019; Rouxel and Balesdent 2017). Allelic series at effector loci can also give rise to qualitative differences in direct recognition specificity by the corresponding host $R$ genes (e.g., the AvrL567 locus in flax rust [Dodds et al. 2006; Ravensdale et al. 2012]). Loss-of-function mutations such as premature stop codons or deletions impair recognition by host surveillance systems of effector functions (Möller and Stukenbrock 2017). Avoiding recognition may also allow pathogens to overcome nonhost resistance (Thines 2019) and acquire the ability to infect new hosts (e.g., loss of PWT3 Avr enabled the emergence of the rice blast fungus as a novel pathogen of wheat [Inoue et al. 2017]).

Although mutation rate is generally thought of as an intrinsic property of each organism (Drake et al. 1998), evidence is emerging that mutation rate bias may be adaptive (Grey Monroe et al. 2020), with some regions of the genome more prone to mutations than others. In Magnaporthe grisea, gain or loss of effector genes is often associated with the unstable telomeric regions of the chromosome (Yoshida et al. 2009). Genomes may be compartmentalized into gene-rich, slow-evolving regions and repeat-rich, gene-sparse regions that exhibit high variability, such as the so-called two-speed genomes of Phytophthora spp. (Dong et al. 2015; Raffaele et al. 2010). Compartmentalization of virulence factors in the genome stands to increase adaptive potential by allowing rapid evolution while minimizing deleterious effects of mutation on housekeeping genes in gene-rich regions. Although by no means universal, similar patterns of compartmentalizing effectors to relatively gene-sparse regions of the genome were found in plant-pathogenic fungi (Leptosphaeria maculans [Rouxel et al. 2011], Zymoseptoria tritici [Stukenbrock et al. 2010], and Colletotrichum higginsianum [Tsushima et al. 2019]), bacteria (Rohmer et al. 2004), and nematodes (Eves-van den Akker et al. 2016). It is not clear in all cases that mutation rates are higher in these compartments; rather, their evolution 
may be the result of the absence of purifying selection. This pattern is not evident in viruses in which mutations in overlapping coding regions and multifunctional proteins may have pleiotropic effects that lead to costs of virulence (García-Arenal and McDonald 2003). In general, empirical estimates of mutation rate for most pathogens remain scarce and the underlying mechanisms unclear (Baer et al. 2007; Tenaillon et al. 2004).

\section{Transposable elements (TEs).}

Gene-sparse regions of the genome are often occupied by TEs. TEs are powerful mutators in prokaryotic and eukaryotic genomes (Möller and Stukenbrock 2017) and may have consequences in surrounding genes, such as deletion, epigenetic silencing, duplication, and recombination, that may provide variation on which natural selection can act (Gijzen et al. 2014; Seidl and Thomma 2017). For example, the insertion of TEs in the sequences of avirulence genes resulted in gain of virulence due to the lack of recognition by the host in Magnaporthe grisea (Fudal et al. 2005; Singh et al. 2019), and gain and loss of genes linked to TEs has been related with the ability to infect different hosts (McDonald et al. 2019; Yoshida et al. 2016). Indeed, 'pathogenicity islands' described in prokaryotes (Kim and Alfano 2002) and some eukaryotes (Eves-van den Akker et al. 2016) are groups of clustered genes involved in pathogenicity (e.g., effectors) that can undergo rapid changes and are frequently flanked by TEs. In some fungi, close proximity of virulence factors to TEs can increase the local mutation rate through repeat-induced point (RIP) mutations. In Leptosphaeria maculans, effector alleles with premature stop codons or nonsynonymous RIP mutations evolved to evade plant resistance mediated by immune receptors in just a few years (Rouxel et al. 2011). Finally, in some cases, TEs have also been neofunctionalized as virulence factors themselves. Botrytis cinerea uses TE-derived sRNA to hijack host RNA interference pathways and suppress plant immunity (Weiberg et al. 2013). In barley powdery mildew, Nottensteiner et al. (2018) demonstrated that the ROPIP1 effector protein derives from a short-interspersed elementrelated TE. In most cases, we do not know why some genomes have many more TEs than others. In powdery mildew fungi, extraordinary proliferation of TEs result in some of the largest genomes in the ascomycete fungi, perhaps due to the absence of the RIP pathway that is otherwise conserved in all related ascomycetes (Spanu et al. 2010).

\section{Duplication and neofunctionalization.}

Duplication and neofunctionalization play important roles in shaping plant-pathogen genomes, in general, and effector repertoires, in particular. The effector repertoires of plant pathogens can number in the hundreds or thousands, yet their evolutionary origins are often unclear (Badet and Croll 2020). Exceptions include horizontal gene transfer (HGT) (discussed below) and effector gene birth by gene duplication and neofunctionalization. This includes the 'weaponization' of TEs (discussed above) and endogenous housekeeping functions as effectors. For example, two large-scale gene multiplication events of the housekeeping glutathione synthetase (GS) resulted in the GS-like effectors of plant-parasitic nematodes. New GS-like paralogues acquired canonical features of an effector (e.g., dorsal gland [DOG] box promoter motif, DOG cell expression, and signal peptide), and the encoded proteins are translocated into host cells (Lilley et al. 2018). Remarkably, the crystal structures of GS-like effectors suggest novel GS paralogues were not just redeployed but also repurposed to carry out a novel biochemical reaction in planta. In addition to explaining the origins of some effectors, the process of gene duplication and neofunctionalization contributes to expansion of certain effector families, regardless of origin. There are several examples of large effector families, with a diversity of functions, linked to a single origin. For example, the WY fold of RXLR effectors is conserved across plant-pathogenic oomycete species (Win et al. 2012), the repeat variable di-residues are characteristic of TAL effectors in Xanthomonas bacterial pathogens (Timilsina et al. 2020), and the SPRY domain, containing proteins that are linked to a single origin in animals but deployed as effectors by pathogenic nematodes and, ultimately, recognized by plants (Sacco et al. 2009).

Beyond the duplication of single effectors or effector gene families, fungal and oomycete pathogens have outstanding chromosome plasticity, with frequent chromosomal aberrations such as aneuploidy or copy number variations resulting from chromosome loss or gain (Covo 2020). Strains of the needle blight pathogen Dothistroma septosporum are aneuploids, with chromosome duplications that result in increased gene copy numbers, which correlate with increased production of the toxin dothistromin (Bradshaw et al. 2019). Host-induced aneuploidy has been proposed for the oomycete Phytophthora ramorum, the causal agent of Sudden Oak Death (Kasuga et al. 2016), and successful strains of the late blight pathogen $P$. infestans exhibit triploidy and aneuploidy (Knaus et al. 2020), although the mechanisms underlying this chromosomal variation and the specific impact on virulence remain unclear.

\section{Genetic exchange within species and kingdoms.}

Genetic exchange (sexual and parasexual) and recombination can give rise to novel virulence activities. Recombination can generate novel combinations of virulence factors and purge deleterious alleles and, thus, has the potential to produce novel virulent phenotypes more rapidly than mutation alone (Grandaubert et al. 2019; Milgroom 2015). For example, the virulent blue13 lineage of $P$. infestans emerged from a sexually recombining population in northern Europe (Cooke et al. 2012). Recombination can also occur in the absence of sex. Although less common, evidence for mitotic crossing over has been shown among clonal lineages in fungi and oomycetes (Milgroom 2015). Mitotic recombination has been associated with genotypic diversity in P. ramorum and P. capsici (Dale et al. 2019; Lamour et al. 2012). Parasexuality in ascomycetes (due to hyphal fusion or anastomosis) and somatic hybridization in dikaryotic basidiomycetes (asexual karyogamy) are mechanisms of asexual exchange of nuclei and recombination (Glass and Dementhon 2006; Park and Wellings 2012). Both phenomena have been demonstrated in the laboratory for many species, but its relevance in nature remains unclear. Anastomosis is the most likely mechanism behind the transfer of accessory chromosomes and HGT between different fungal lineages or species (Soanes and Richards 2014). Presence or absence of accessory or dispensable chromosomes have been associated with host specialization (Mirocha et al. 1992; Temporini and VanEtten 2004). Indeed, the transfer of accessory chromosomes to nonpathogenic isolates can be sufficient to generate a virulent pathogen ( $\mathrm{Li}$ et al. $2020 \mathrm{~b}$ ). The acquisition of novel virulence activities through HGT has been documented in several cases (Soanes and Richards 2014)

Hybridization, defined here as the combining of two phylogenetically distinct genomes, can result in novel genotypes. Hybrids may be reproductively isolated or continued backcrossing with parental genotypes can result in the introgression of regions of one parental genome into the other parental genome. Multiple examples are found in fungi, oomycetes, and nematodes (Eves-van den Akker and Jones 2018; Feurtey and Stukenbrock 2018). For example, analysis of Z. tritici genomes showed evidence of repeated introgression from other Zymoseptoria species, including regions containing effectors (Feurtey et al. 2019). A similar pattern of introgression was found among host-specific races of the oomycete Albugo candida (McMullan et al. 2015). 
By contrast, Z. pseudotritici appears to have originated from a single hybridization event and has remained reproductively isolated from its parental species, as evidenced by its clonal population and the mosaic structure of its genome (Stukenbrock et al. 2012).

Intra-and interspecific hybridization events can expand the host range of hybrid offspring and therefore must confer novel virulence activities. Several Phytophthora hybrids show enhanced virulence (Brasier et al. 2004) or expanded host range (Jafari et al. 2020). Blumeria graminis f. sp. triticale is a hybrid of wheat pathogen $B$. graminis f. sp tritici and rye pathogen B. graminis f. sp secalis (Menardo et al. 2016). The hybrid $B$. graminis f. sp. triticale can infect the artificial wheat-rye hybrid triticale, whereas the parental pathogens cannot. It is not yet clear how hybridization changed this host-pathogen interaction. Wheat stem rust caused by Puccinia graminis f. sp. tritici was controlled for more than 30 years, thanks to wheat varieties carrying stem rust resistance gene $\mathrm{Sr} 31$, until Ug99 overcame Sr31 resistance and rapidly expanded in East and South Africa and the Near East (Singh et al. 2011). Genomic evidence suggests that Ug99 emerged by somatic hybridization and nuclear exchange between two dikaryons followed by the loss-of-function of an effector ( $\mathrm{Li}$ et al. 2019). Some plant-parasitic nematodes in the genus Meloidogyne have a polyploid origin consistent with hybridization (allopolyploidy [Trudgill and Blok 2001]), with a further study suggesting some species (e.g., Meloidogyne incognita) result from multiple, additive, hybridization events (Lunt et al. 2014). These hybrids are parthenogenetic, yet can overcome host resistance in the absence of sex (CastagnoneSereno 2006) and have a broader host range, wider geographical distribution, and greater agricultural impact than their sexual relatives (Blanc-Mathieu et al. 2017). The extraordinarily broad host range of the asexual hybrid Meloidogyne incognita (several thousand hosts) includes representatives from most orders of flowering plants (Eves-van den Akker and Jones 2018). While there are now numerous examples of hybrid plant pathogens (Depotter et al. 2016), the specific genetic mechanisms that increase virulence or host range of hybrids are largely unknown. Gain of effector function or, at least, gain of genetic capital for neofunctionalization (as discussed above) is plausible but by no means a satisfactory explanation for some of the more dramatic increases in host range.

Recombination in virus populations (i.e., the exchange of genomic fragments between genotypes) can occur between genotypes of the same or of different virus species (Pagán and García-Arenal 2019), and the emergence of new viral lineages with enhanced virulence and enlarged or different host ranges is, in many cases, explained by recombination events (Monci et al. 2002; Ruiz et al. 2018; van der Walt et al. 2009). The contribution of recombination to the generation of virus genetic diversity is comparable to that of mutation, despite the exclusive clonal multiplication of these pathogens. In RNA viruses, recombination is due to copy choice template switching during RNA replication, while in DNA viruses the mechanisms are less understood and may involve double-strand (ds) break repair events on dsDNA intermediates using host cell factors. In all viral types, recombination breakpoints within coding regions are rare, probably because these are selected against (Lefeuvre et al. 2009). Genetic exchange in virus populations may also result from reassortment of genomic segments in viruses with segmented or multipartite genomes, in a process that is also known as pseudorecombination (Varsani et al. 2018). Multipartite genomes are frequent among plant viruses, despite the cost for transmission if most segments must be transmitted between hosts to cause new infections (Zwart and Elena 2020). Reassortment is strongly related with virus evolution and speciation, and it is seen as an advantage for multipartite viruses because of the possibilities of generating fitter variants (Roossinck 2005). However, there are constraints in the generation of reassortants during coinfection, such as incompatible RNA-RNA or proteinRNA interactions from different viral strains, that may prevent them from prevailing in the population (Bonnet et al. 2005; McDonald et al. 2016).

Bacterial plant pathogens are efficient in acquiring existing virulence factors via HGT. Emerging strains of Pseudomonas syringae on cucurbits show convergent acquisition of hrp/hrc genes and effectors, among other genes, across phylogenetically distinct groups (Newberry et al. 2019). These genes appear to have been horizontally transferred in integrated conjugative elements and on plasmids. Similar patterns of convergent host specificity in phylogenetically distinct lineages via HGT of hrp/hrc gene clusters have been reported for Acidovorax avenae (Zeng et al. 2017). In Xanthomonas, host range expansion of $X$. perforans from tomato to pepper is associated with extensive recombination from sister taxon and pepper pathogen X. euvesicatoria (Newberry et al. 2019; Schwartz et al. 2015; Timilsina et al. 2020), both members of the $X$. euvesicatoria species complex (Barak et al. 2016).

\section{Genetic exchange between kingdoms.}

Since the first discovery of a cellulase in an animal (Smant et al. 1998), HGT events from bacteria and fungi to plantparasitic nematodes have been recognized as surprisingly numerous (conservatively $0.6 \%$ of genes [Eves-van den Akker et al. 2016]) and an important catalyst for the evolution of parasitism (Haegeman, Jones, and Danchin 2011). Interesting examples include pseudo-convergent transfer of specific functions, for example a GH45 cellulase from fungi to Bursaphelenchus xylophilus (Kikuchi et al. 2004) and the GH5 cellulase from a bacteria to various members of family Heteroderidae (Cotton et al. 2014; Danchin et al. 2010; Eves-van den Akker et al. 2016). Genome-wide analyses have expanded the complement beyond 'effector proteins' to metabolism, vitamin biosynthesis, and more (Eves-van den Akker et al. 2016; Moran and Jarvik 2010). Despite apparent widespread transfer from bacteria and some eukaryotes to nematodes, there is a conspicuous absence of transfer from oomycetes, viruses, and plants (although examples of the latter exist in plant-parasitic plants [Yang et al. 2019]).

Fungi and oomycetes are similarly recipients of horizontally transferred genes from other kingdoms that are involved in virulence activities, such as a subtilisin serine protease-encoding gene from a plant donor to an ancestor of Colletotrichum fungi (Armijos Jaramillo et al. 2013), a glucan glucosyltransferaseencoding gene from bacteria that probably allows vascular fungi to survive in the high osmotic conditions of plant xylem (Klosterman et al. 2011). and the necrosis- and ethylene-inducing peptide 1 (NEP1)-like proteins that oomycetes have probably acquired from ascomycetes (Richards et al. 2011). In general, we have well-characterized examples of genetic transfer events that give rise to virulence activities but it is not clear how often these phenomena occur in the field and whether novel virulence more often evolves de novo or via the transfer of existing virulence factors from some other system.

\section{CONCLUDING REMARKS}

We return to the question How do pathogens evolve novel virulence activities? This review tells us that if there is an epigenetic or genetic mechanism that can create variation in the genome (characterized or otherwise), it will be used by pathogens to evolve virulence factors. We may think that we know quite a lot about how pathogens evolve virulence but there are many unexplored areas and questions (Box 1). It seems the most common form of evolution of virulence is the classical 


\section{BOX 1. OUTSTANDING QUESTIONS AND TOPICS IN RELATION TO HOW PATHOGENS EVOLVE NOVEL VIRULENCE ACTIVITIES}

\section{Effectors}

- While much of our knowledge has been directed to understanding effector evolution to evade host immunity, there is still much to learn about effector adaptation to newly evolved or existing host factors.

- The precise function of effectors and their host targets are still unknown in many cases. Why do some effectors make a relatively greater contribution to novel virulence activities?

- To what extent do nonproteinaceous molecules (nucleic acids, pathogen-derived small molecules, metabolites, and lipids) contribute to virulence activities and are they encompassed by existing evolutionary models?

\section{Models of plant-pathogen interaction}

- It is generally assumed that there is a cost of virulence activities in the absence of selection, although the impact of the costs, and how to measure them, are not yet fully resolved.

- While gene for gene and matching allele interactions are reasonably numerous and well characterized because they are relatively simple, increasing evidence points to interactions being more complex than previously described

\section{Pathogenic traits, life cycle, and trade-offs}

- What is the involvement of virulence factors in pathogen life-stages other than infection?

- Experimental data about trade-offs in the evolution of virulence activities are often contradictory.

- Little is known about the molecular mechanisms that restrict pathogen virulence.

- The molecular mechanisms associated with adaptive evolution of host-specific lineages of a multihost plant pathogen remain mostly poorly understood. We still do not know most of the key steps that lead to the adaptation to a new host and, thus, determine pathogen host range.

- Ecological complexity also affects evolutionary trajectories of pathogens, and more research using multihost and multipathogen systems is needed to understand the consequences for virulence activities.

\section{Mechanisms for acquiring novel virulence activities}

- In general, empirical estimates of mutation rate for most pathogens remain scarce and the underlying mechanisms unclear. What are the mechanisms underlying chromosomal variation and what is its specific impact on virulence?

- What is the relevance in nature of parasexuality and how often do genetic transfer events that give rise to novel virulence activities occur in the field?

- The underlying mechanisms of HGT between different species and kingdoms are mostly unknown.

- What are the specific genetic mechanisms that increase virulence or host range of hybrids?

- Does novel virulence more often evolve de novo or via the transfer of existing virulence factors from some other system?

loss of an avr, but this may be due to a bias in research rather than a reflection of reality. There are many other virulence activities during the life stages of the pathogen that are underexplored as well as the effects of actors other than the host (i.e., biotic and abiotic factors in the ecosystem) on the evolution of pathogen virulence activities. More studies are needed to disentangle the involvement of virulence factors in pathogen life stages other than infection and the implications in coevolutionary processes and adaptation to new hosts (Morris and Moury 2019).

Understanding the key driving forces that give rise to novel virulence activities in agricultural and wild settings may help inform crop protection. For example, given the diversity of mechanisms and the veritable certainty of the evolution of pathogens, perhaps the focus should be on not just the stacking of several arbitrary sources of resistance but, rather, the stacking of sources of resistance that require very different mechanisms of evolution to overcome. In order to approach these strategies, the integration of evolutionary concepts and methods with mechanistic research on plant-microbe interactions is necessary (Upson et al. 2018).

Virulence activities are just one of the many strategies microorganisms deploy to maximize fitness in their interaction with plants. The range of interactions between plants and microorganisms extends from pathogenic to beneficial with multiple forms in between (Hardoim et al. 2015). Quite often, genotypes exhibit phenotypic plasticity or evolutionary tradeoffs mediated by the biotic interactions, the abiotic environment, or a combination thereof (Brader et al. 2017; Hacquard et al. 2016; Hardoim et al. 2015; Muñoz-Barrios et al. 2020). Pathogens and beneficial microorganisms share many tools and mechanisms in their interaction with the host (Paszkowski 2006). The number 1 Top 10 question, How do plants engage with beneficial microorganisms while at the same time restricting pathogens? (Harris et al. 2020), was discussed in the MPMI May 2021 issue. The question 'how do pathogens evolve novel virulence activities?' leads to the more general "why do microorganisms evolve virulence activities?'. There are probably as many answers to these questions as there are evolutionary pathways for microorganisms to become virulent.

\section{LITERATURE CITED}

Abrahamian, P., Timilsina, S., Minsavage, G. V., Kc, S., Goss, E. M., Jones, J. B., and Vallad, G. E. 2018. The type III effector AvrBsT enhances Xanthomonas perforans fitness in field-grown tomato. Phytopathology 108:1355-1362.

Alizon, S., Hurford, A., Mideo, N., and Van Baalen, M. 2009. Virulence evolution and the trade-off hypothesis: History, current state of affairs and the future. J. Evol. Biol. 22:245-259.

Anderson, R. M., and May, R. M. 1982. Coevolution of hosts and parasites. Parasitology 85:411-426.

Antonovics, J., Boots, M., Ebert, D., Koskella, B., Poss, M., and Sadd, B. M. 2013. The origin of specificity by means of natural selection: Evolved and nonhost resistance in host-pathogen interactions. Evolution 67:1-9.

Armijos Jaramillo, V. D., Vargas, W. A., Sukno, S. A., and Thon, M. R. 2013. Horizontal transfer of a subtilisin gene from plants into an ancestor of the plant pathogenic fungal genus Colletotrichum. PLoS One 8:e59078.

Badet, T., and Croll, D. 2020. The rise and fall of genes: Origins and functions of plant pathogen pangenomes. Curr. Opin. Plant Biol. 56:65-73.

Baer, C. F., Miyamoto, M. M., and Denver, D. R. 2007. Mutation rate variation in multicellular eukaryotes: Causes and consequences. Nat. Rev. Genet. 8:619-631.

Barak, J. D., Vancheva, T., Lefeuvre, P., Jones, J. B., Timilsina, S. Minsavage, G. V., Vallad, G. E., and Koebnik, R. 2016. Whole-genome sequences of Xanthomonas euvesicatoria strains clarify taxonomy and reveal a stepwise erosion of type 3 effectors. Front. Plant Sci. 7:1805.

Barrett, L. G., and Heil, M. 2012. Unifying concepts and mechanisms in the specificity of plant-enemy interactions. Trends Plant Sci. 17:282-292.

Bartoli, C., Roux, F., and Lamichhane, J. R. 2016. Molecular mechanisms underlying the emergence of bacterial pathogens: An ecological perspective. Mol. Plant Pathol. 17:303-310. 
Bebber, D. P. 2015. Range-expanding pests and pathogens in a warming world. Annu. Rev. Phytopathol. 53:335-356.

Bedhomme, S., Hillung, J., and Elena, S. F. 2015. Emerging viruses: Why they are not jacks of all trades? Curr. Opin. Virol. 10:1-6.

Bera, S., Fraile, A., and García-Arenal, F. 2018. Analysis of fitness trade-offs in the host range expansion of an RNA virus, tobacco mild green mosaic virus. J. Virol. 92:e01268-18.

Blanc-Mathieu, R., Perfus-Barbeoch, L., Aury, J.-M., Da Rocha, M., Gouzy, J., Sallet, E., Martin-Jimenez, C., Bailly-Bechet, M., CastagnoneSereno, P., Flot, J. F., Kozlowski, D. K., Cazareth, J., Couloux, A., Da Silva, C., Guy, J., Kim-Jo, Y. J., Rancurel, C., Schiex, T., Abad, P., Wincker, P., and Danchin, E. G. J. 2017. Hybridization and polyploidy enable genomic plasticity without sex in the most devastating plant-parasitic nematodes. PLoS Genet. 13:e1006777.

Bonnet, J., Fraile, A., Sacristán, S., Malpica, J. M., and García-Arenal, F. 2005. Role of recombination in the evolution of natural populations of Cucumber mosaic virus, a tripartite RNA plant virus. Virology 332:359368

Brader, G., Compant, S., Vescio, K., Mitter, B., Trognitz, F., Ma, L.-J., and Sessitsch, A. 2017. Ecology and genomic insights into plant-pathogenic and plant-nonpathogenic endophytes. Annu. Rev. Phytopathol. 55:61-83.

Bradshaw, R. E., Sim, A. D., Chettri, P., Dupont, P.-Y., Guo, Y., Hunziker, L., McDougal, R. L., Van der Nest, A., Fourie, A., Wheeler, D., Cox, M. P., and Barnes, I. 2019. Global population genomics of the forest pathogen Dothistroma septosporum reveal chromosome duplications in high dothistromin-producing strains. Mol. Plant Pathol. 20:784-799.

Brasier, C. M., Kirk, S. A., Delcan, J., Cooke, D. E. L., Jung, T., and Man in't Veld, W. A. 2004. Phytophthora alni sp. nov. and its variants: Designation of emerging heteroploid hybrid pathogens spreading on Alnus trees. Mycol. Res. 108:1172-1184.

Brown, J. K. M., and Tellier, A. 2011. Plant-parasite coevolution: Bridging the gap between genetics and ecology. Annu. Rev. Phytopathol. 49:345-367

Brunings, A. M., and Gabriel, D. W. 2003. Xanthomonas citri: Breaking the surface. Mol. Plant Pathol. 4:141-157.

Bruns, E., Carson, M., and May, G. 2012. Pathogen and host genotype differently affect pathogen fitness through their effects on different life-history stages. BMC Evol. Biol. 12:135.

Burdon, J. J., and Thrall, P. H. 2009. Coevolution of plants and their pathogens in natural habitats. Science 324:755-756.

Büttner, D. 2016. Behind the lines-actions of bacterial type III effector proteins in plant cells. FEMS Microbiol. Rev. 40:894-937.

Camborde, L., Raynaud, C., Dumas, B., and Gaulin, E. 2019. DNAdamaging effectors: New players in the effector arena. Trends Plant Sci. 24:1094-1101.

Castagnone-Sereno, P. 2006. Genetic variability and adaptive evolution in parthenogenetic root-knot nematodes. Hered. Edinb 96:282-289.

Chaloner, T. M., Gurr, S. J., and Bebber, D. P. 2020. Geometry and evolution of the ecological niche in plant-associated microbes. Nat. Commun. 11:2955.

Chen, F., Duan, G.-H., Li, D.-L., and Zhan, J. 2017. Host resistance and temperature-dependent evolution of aggressiveness in the plant pathogen Zymoseptoria tritici. Front. Microbiol. 8:1217.

Cho, Y., Srivastava, A., Ohm, R. A., Lawrence, C. B., Wang, K.-H., Grigoriev, I. V., and Marahatta, S. P. 2012. Transcription factor Amr1 induces melanin biosynthesis and suppresses virulence in Alternaria brassicicola. PLoS Pathog. 8:e1002974.

Choi, G. H., and Nuss, D. L. 1992. Hypovirulence of chestnut blight fungus conferred by an infectious viral cDNA. Science 257:800-803.

Cobos, A., Montes, N., López-Herranz, M., Gil-Valle, M., and Pagán, I. 2019. Within-host multiplication and speed of colonization as infection traits associated with plant virus vertical transmission. J. Virol. 93:e01078-19.

Cooke, D. E. L., Cano, L. M., Raffaele, S., Bain, R. A., Cooke, L. R., Etherington, G. J., Deahl, K. L., Farrer, R. A., Gilroy, E. M., Goss, E. M., Grünwald, N. J., Hein, I., MacLean, D., McNicol, J. W., Randall, E., Oliva, R. F., Pel, M. A., Shaw, D. S., Squires, J. N. Taylor, M. C., Vleeshouwers, V. G., Birch, P. R., Lees, A. K., and Kamoun, S. 2012. Genome analyses of an aggressive and invasive lineage of the Irish potato famine pathogen. PLoS Pathog. 8:e1002940.

Cotton, J. A., Lilley, C. J., Jones, L. M., Kikuchi, T., Reid, A. J., Thorpe, P., Tsai, I. J., Beasley, H., Blok, V., Cock, P. J. A., Eves-van den Akker, S., Holroyd, N., Hunt, M., Mantelin, S., Naghra, H., Pain, A., Palomares-Rius, J. E., Zarowiecki, M., Berriman, M., Jones, J. T., and Urwin, P. E. 2014. The genome and life-stage specific transcriptomes of Globodera pallida elucidate key aspects of plant parasitism by a cyst nematode. Genome Biol. 15:R43.
Covo, S. 2020. Genomic instability in fungal plant pathogens. Genes (Basel) 11:421.

Cox, K. L., Meng, F., Wilkins, K. E., Li, F., Wang, P., Booher, N. J., Carpenter, S. C. D., Chen, L. Q., Zheng, H., Gao, X., Zheng, Y., Fei, Z., Yu, J. Z., Isakeit, T., Wheeler, T., Frommer, W. B., He, P., Bogdanove, A. J., and Shan, L. 2017. TAL effector driven induction of a SWEET gene confers susceptibility to bacterial blight of cotton. Nat. Commun. 8:15588.

D’Arcy, C. J., Eastburn, D. M., and Schumann, G. L. 2001. Illustrated glossary of plant pathology. The Plant Health Instruct. .

Dale, A. L., Feau, N., Everhart, S. E., Dhillon, B., Wong, B., Sheppard, J., Bilodeau, G. J., Brar, A., Tabima, J. F., Shen, D., Brasier, C. M., Tyler, B. M., Grünwald, N. J., and Hamelin, R. C. 2019. Mitotic recombination and rapid genome evolution in the invasive forest pathogen Phytophthora ramorum. MBio 10:e02452-18.

Danchin, E. G. J., Rosso, M.-N., Vieira, P., de Almeida-Engler, J., Coutinho, P. M., Henrissat, B., and Abad, P. 2010. Multiple lateral gene transfers and duplications have promoted plant parasitism ability in nematodes. Proc. Natl. Acad. Sci. U.S.A. 107:17651-17656.

Depotter, J. R., Seidl, M. F., Wood, T. A., and Thomma, B. P. 2016. Interspecific hybridization impacts host range and pathogenicity of filamentous microbes. Curr. Opin. Microbiol. 32:7-13.

de Vries, S., Stukenbrock, E. H., and Rose, L. E. 2020. Rapid evolution in plant-microbe interactions-An evolutionary genomics perspective. New Phytol. 226:1256-1262.

Dillon, M. M., Almeida, R. N. D., Laflamme, B., Martel, A., Weir, B. S., Desveaux, D., and Guttman, D. S. 2019. Molecular evolution of Pseudomonas syringae type III secreted effector proteins. Front. Plant Sci. 10:418.

Dodds, P. N., Lawrence, G. J., Catanzariti, A.-M., and Teh, T., Wang, C.-I A., Ayliffe, M. A., Kobe, B., and Ellis, J. G. 2006. Direct protein interaction underlies gene-for-gene specificity and coevolution of the flax resistance genes and flax rust avirulence genes. Proc. Natl.Acad. Sci. U.S.A. 103:8888-8893.

Dodds, P. N., and Rathjen, J. P. 2010. Plant immunity: Towards an integrated view of plant-pathogen interactions. Nat. Rev. Genet. 11:539-548.

Dong, S., Raffaele, S., and Kamoun, S. 2015. The two-speed genomes of filamentous pathogens: Waltz with plants. Curr. Opin. Genet. Dev. 35:57-65.

Drake, J. W., Charlesworth, B., Charlesworth, D., and Crow, J. F. 1998. Rates of spontaneous mutation. Genetics. 148:1667-1686.

Dutta, A., Croll, D., McDonald, B. A., and Barrett, L. G. 2021. Maintenance of variation in virulence and reproduction in populations of an agricultural plant pathogen. Evol. Appl. 14:335-347.

Elena, S. F., Fraile, A., and García-Arenal, F. 2014. Evolution and emergence of plant viruses. Adv. Virus Res. 88:161-191.

Eves-van den Akker, S., and Jones, J. T. 2018. Sex: Not all that it's cracked up to be? PLoS Genet. 14:e1007160.

Eves-van den Akker, S., Laetsch, D. R., Thorpe, P., Lilley, C. J., Danchin, E. G. J., Da Rocha, M., Rancurel, C., Holroyd, N. E., Cotton, J. A., Szitenberg, A., Grenier, E., Montarry, J., Mimee, B., Duceppe M. O., Boyes, I., Marvin, J. M., Jones, L. M., Yusup, H. B., LafondLapalme, J., Esquibet, M., Sabeh, M., Rott, M., Overmars, H., Finkers-Tomczak, A., Smant, G., Koutsovoulos, G., Blok, V., Mantelin, S., Cock, P. J., Phillips, W., Henrissat, B., Urwin, P. E. Blaxter, M., and Jones, J. T. 2016. The genome of the yellow potato cyst nematode, Globodera rostochiensis, reveals insights into the basis of parasitism and virulence. Genome Biol. 17:124.

Ewald, P. W. 1983. Host-parasite relations, vectors, and the evolution of disease severity. Annu. Rev. Ecol. Syst. 14:465-485.

Feurtey, A., Stevens, D. M., Stephan, W., and Stukenbrock, E. H. 2019. Interspecific gene exchange introduces high genetic variability in crop pathogen. Genome Biol. Evol. 11:3095-3105.

Feurtey, A., and Stukenbrock, E. H. 2018. Interspecific gene exchange as a driver of adaptive evolution in fungi. Annu. Rev. Microbiol. 72:377-398.

Frantzeskakis, L., Di Pietro, A., Rep, M., Schirawski, J., Wu, C. H., and Panstruga, R. 2020. Rapid evolution in plant-microbe interactions-A molecular genomics perspective. New Phytol. 225:1134-1142.

Fudal, I., Böhnert, H. U., Tharreau, D., and Lebrun, M.-H. 2005. Transposition of MINE, a composite retrotransposon, in the avirulence gene $A C E 1$ of the rice blast fungus Magnaporthe grisea. Fungal Genet. Biol. 42:761-772.

García-Arenal, F., and McDonald, B. A. 2003. An analysis of the durability of resistance to plant viruses. Phytopathology 93:941-952.

Gijzen, M., Ishmael, C., and Shrestha, S. D. 2014. Epigenetic control of effectors in plant pathogens. Front. Plant Sci. 5:638. 
Gilbert, G. S., Magarey, R., Suiter, K., and Webb, C. O. 2012. Evolutionary tools for phytosanitary risk analysis: Phylogenetic signal as a predictor of host range of plant pests and pathogens. Evol. Appl. 5:869-878.

Glass, N. L., and Dementhon, K. 2006. Non-self recognition and programmed cell death in filamentous fungi. Curr. Opin. Microbiol. 9:553-558.

Graham, J. H., Gottwald, T. R., Cubero, J., and Achor, D. S. 2004. Xanthomonas axonopodis pv. citri: Factors affecting successful eradication of citrus canker. Mol. Plant Pathol. 5:1-15.

Grandaubert, J., Dutheil, J. Y., and Stukenbrock, E. H. 2019. The genomic determinants of adaptive evolution in a fungal pathogen. Evol. Lett. 3:299-312.

Grey Monroe, J. Srikant, T., Carbonell-Bejerano, P., Exposito-Alonso, M., Weng, M.-L., Rutter, M. T., Fenster, C. B., and Weigel, D. 2020. Mutation bias shapes gene evolution in Arabidopsis thaliana. bioRxiv. Published online.

Hacquard, S., Kracher, B., Hiruma, K., Münch, P. C., Garrido-Oter, R., Thon, M. R., Weimann, A., Damm, U., Dallery, J. F., Hainaut, M., Henrissat, B., Lespinet, O., Sacristán, S., Ver Loren van Themaat, E., Kemen, E., McHardy, A. C., Schulze-Lefert, P., and O'Connell, R. J. 2016. Survival trade-offs in plant roots during colonization by closely related beneficial and pathogenic fungi. Nat. Commun. 7:11362.

Haegeman, A., Jones, J. T., and Danchin, E. G. J. 2011. Horizontal gene transfer in nematodes: A catalyst for plant parasitism? Mol. PlantMicrobe Interact. 24:879-887.

Hardoim, P. R., van Overbeek, L. S., Berg, G., Pirttilä, A. M., Compant, S., Campisano, A., Döring, M., and Sessitsch, A. 2015. The hidden world within plants: Ecological and evolutionary considerations for defining functioning of microbial endophytes. Microbiol. Mol. Biol. Rev. 79:293-320.

Harris, J. M., Balint-Kurti, P., Bede, J. C., Day, B., Gold, S., Goss, E. M., Grenville-Briggs, L. J., Jones, K. M., Wang, A., Wang, Y., Mitra, R. M., Sohn, K. H., and Alvarez, M. E. 2020. What are the top 10 unanswered questions in molecular plant-microbe interactions? Mol. Plant-Microbe Interact. 33:1354-1365.

Hassani, M. A., Durán, P., and Hacquard, S. 2018. Microbial interactions within the plant holobiont. Microbiome 6:58.

Hébrard, E., Poulicard, N., Gérard, C., Traoré, O., Wu, H.-C., Albar, L., Fargette, D., Bessin, Y., and Vignols, F. 2010. Direct interaction between the Rice yellow mottle virus (RYMV) VPg and the central domain of the rice eIF(iso)4G1 factor correlates with rice susceptibility and RYMV virulence. Mol. Plant-Microbe Interact. 23:1506-1513.

Henson, J. M., Butler, M. J., and Day, A. W. 1999. The dark side of the mycelium: Melanins of phytopathogenic fungi. Annu. Rev. Phytopathol. 37:447-471.

Huang, X., Sun, M., Lu, X., and Li, S. 2019. Serial passage through resistant and susceptible cucumber cultivars affects the virulence of Fusarium oxysporum f. sp. cucumerinum. MicrobiologyOpen 8:e0641.

Inoue, Y., Vy, T. T. P., Yoshida, K., Asano, H., Mitsuoka, C., Asuke, S., Anh, V. L., Cumagun, C. J. R., Chuma, I., Terauchi, R., Kato, K., Mitchell, T., Valent, B., Farman, M., and Tosa, Y. 2017. Evolution of the wheat blast fungus through functional losses in a host specificity determinant. Science 357:80-83

Jafari, F., Mostowfizadeh-Ghalamfarsa, R., Safaiefarahani, B., and Burgess, T. I. 2020. Potential host range of four Phytophthora interspecific hybrids from clade 8a. Plant Pathol. 69:1281-1290.

Jones, J. D. G. 2019. Flor-iculture: Ellis and Dodds' illumination of gene-for-gene biology. Plant Cell 31:1204-1205.

Jones, J. D. G., and Dangl, J. L. 2006. The plant immune system. Nature 444:323-329.

Jones, R. A. C. 2009. Plant virus emergence and evolution: Origins, new encounter scenarios, factors driving emergence, effects of changing world conditions, and prospects for control. Virus Res. 141:113-130.

Kasuga, T., Bui, M., Bernhardt, E., Swiecki, T., Aram, K., Cano, L. M., Webber, J., Brasier, C., Press, C., Grünwald, N. J., Rizzo, D. M., and Garbelotto, M. 2016. Host-induced aneuploidy and phenotypic diversification in the Sudden Oak Death pathogen Phytophthora ramorum. BMC Genomics 17:385.

Kettles, G. J., Bayon, C., Sparks, C. A., Canning, G., Kanyuka, K., and Rudd, J. J. 2018. Characterization of an antimicrobial and phytotoxic ribonuclease secreted by the fungal wheat pathogen Zymoseptoria tritici. New Phytol. 217:320-331.

Kikuchi, T., Jones, J. T., Aikawa, T., Kosaka, H., and Ogura, N. 2004. A family of glycosyl hydrolase family 45 cellulases from the pine wood nematode Bursaphelenchus xylophilus. FEBS Lett. 572:201-205.

Killiny, N., Martinez, R. H., Dumenyo, C. K., Cooksey, D. A., and Almeida, R. P. P. 2013. The exopolysaccharide of Xylella fastidiosa is essential for biofilm formation, plant virulence, and vector transmission. Mol. Plant-Microbe Interact. 26:1044-1053.

Kim, J. F., and Alfano, J. R. 2002. Pathogenicity islands and virulence plasmids of bacterial plant pathogens. Curr. Top. Microbiol. Immunol. 264:127-147.

Kirchner, J. W., and Roy, B. A. 2000. Evolutionary implications of hostpathogen specificity: The fitness consequences of host life history traits. Evol. Ecol. 14:665-692.

Klosterman, S. J., Subbarao, K. V., Kang, S., Veronese, P., Gold, S. E., Thomma, B. P. H. J., Chen, Z., Henrissat, B., Lee, Y. H., Park, J., Garcia-Pedrajas, M. D., Barbara, D. J., Anchieta, A., de Jonge, R., Santhanam, P., Maruthachalam, K., Atallah, Z., Amyotte, S. G., Paz, Z., Inderbitzin, P., Hayes, R. J., Heiman, D. I., Young, S., Zeng, Q., Engels, R., Galagan, J., Cuomo, C. A., Dobinson, K. F., and Ma, L. J. 2011. Comparative genomics yields insights into niche adaptation of plant vascular wilt pathogens. PLoS Pathog. 7:e1002137.

Knaus, B. J., Tabima, J. F., Shakya, S. K., Judelson, H. S., and Grünwald, N. J. 2020. Genome-wide increased copy number is associated with emergence of dominant clones of the Irish potato famine pathogen Phytophthora infestans. MBio 11:e00326-20.

Lamour, K. H., Mudge, J., Gobena, D., Hurtado-Gonzales, O. P., Schmutz, J., Kuo, A., Miller, N. A., Rice, B. J., Raffaele, S., Cano, L. M., Bharti, A. K., Donahoo, R. S., Finley, S., Huitema, E., Hulvey, J., Platt, D., Salamov, A., Savidor, A., Sharma, R., Stam, R., Storey, D., Thines, M., Win, J., Haas, B. J., Dinwiddie, D. L., Jenkins, J., Knight, J. R., Affourtit, J. P., Han, C. S., Chertkov, O., Lindquist, E. A., Detter, C., Grigoriev, I. V., Kamoun, S., and Kingsmore, S. F. 2012. Genome sequencing and mapping reveal loss of heterozygosity as a mechanism for rapid adaptation in the vegetable pathogen Phytophthora capsici. Mol. Plant-Microbe Interact. 25:1350-1360.

Lefeuvre, P., Lett, J.-M., Varsani, A., and Martin, D. P. 2009. Widely conserved recombination patterns among single-stranded DNA viruses. J. Virol. 83:2697-2707.

Leisner, S. M., and Schoelz, J. E. 2018. Joining the crowd: Integrating plant virus proteins into the larger world of pathogen effectors. Annu. Rev. Phytopathol. 56:89-110.

Li, F., Upadhyaya, N. M., Sperschneider, J., Matny, O., Nguyen-Phuc, H., Mago, R., Raley, C., Miller, M. E., Silverstein, K. A. T., Henningsen, E., Hirsch, C. D., Visser, B., Pretorius, Z. A., Steffenson, B. J., Schwessinger, B., Dodds, P. N., and Figueroa, M. 2019. Emergence of the Ug99 lineage of the wheat stem rust pathogen through somatic hybridisation. Nat. Commun. 10:5068.

Li, J., Cornelissen, B., and Rep, M. 2020a. Host-specificity factors in plant pathogenic fungi. Fungal Genet. Biol. 144:103447.

Li, J., Fokkens, L., van Dam, P., and Rep, M. 2020b. Related mobile pathogenicity chromosomes in Fusarium oxysporum determine host range on cucurbits. Mol. Plant Pathol. 21:761-776.

Li, P., and Day, B. 2019. Battlefield cytoskeleton: Turning the tide on plant immunity. Mol. Plant-Microbe Interact. 32:25-34.

Lilley, C. J., Maqbool, A., Wu, D., Yusup, H. B., Jones, L. M., Birch, P. R. J., Banfield, M. J., Urwin, P. E., and Eves-van den Akker, S 2018. Effector gene birth in plant parasitic nematodes: Neofunctionalization of a housekeeping glutathione synthetase gene. PLoS Genet. 14:e1007310.

Lo Presti, L., Lanver, D., Schweizer, G., Tanaka, S., Liang, L., Tollot, M., Zuccaro, A., Reissmann, S., and Kahmann, R. 2015. Fungal effectors and plant susceptibility. Annu. Rev. Plant Biol. 66:513-545.

Lunt, D. H., Kumar, S., Koutsovoulos, G., and Blaxter, M. L. 2014. The complex hybrid origins of the root knot nematodes revealed through comparative genomics. PeerJ 2:e356.

Mascia, T., and Gallitelli, D. 2016. Synergies and antagonisms in virus interactions. Plant Sci. 252:176-192.

McDonald, B. A., and Stukenbrock, E. H. 2016. Rapid emergence of pathogens in agro-ecosystems: Global threats to agricultural sustainability and food security. Philos. Trans. R. Soc. Lond. B Biol. Sci. 371:20160026.

McDonald, M. C., and Solomon, P. S. 2018. Just the surface: Advances in the discovery and characterization of necrotrophic wheat effectors. Curr. Opin. Microbiol. 46:14-18.

McDonald, M. C., Taranto, A. P., Hill, E., Schwessinger, B., Liu, Z., Simpfendorfer, S., Milgate, A., and Solomon, P. S. 2019. Transposonmediated horizontal transfer of the host-specific virulence protein toxa between three fungal wheat pathogens. MBio 10:e01515-19.

McDonald, S. M., Nelson, M. I., Turner, P. E., and Patton, J. T. 2016 Reassortment in segmented RNA viruses: Mechanisms and outcomes. Nat. Rev. Microbiol. 14:448-460. 
McLeish, M., Sacristán, S., Fraile, A., and García-Arenal, F. 2017. Scale dependencies and generalism in host use shape virus prevalence. Proc. Natl. Acad. Sci. U.S.A. 284:2066.

McLeish, M. J., Fraile, A., and García-Arenal, F. 2018. Ecological complexity in plant virus host range evolution. Adv. Virus Res. 101:293-339.

McMullan, M., Gardiner, A., Bailey, K., Kemen, E., Ward, B. J., Cevik, V., Robert-Seilaniantz, A., Schultz-Larsen, T., Balmuth, A., Holub, E., van Oosterhout, C., and Jones, J. D. G. 2015. Evidence for suppression of immunity as a driver for genomic introgressions and host range expansion in races of Albugo candida, a generalist parasite. Elife. 4:e04550.

Menardo, F., Praz, C. R., Wyder, S., Ben-David, R., Bourras, S., Matsumae, H., McNally, K. E., Parlange, F., Riba, A., Roffler, S., Schaefer, L. K., Shimizu, K. K., Valenti, L., Zbinden, H., Wicker, T., and Keller, B. 2016. Hybridization of powdery mildew strains gives rise to pathogens on novel agricultural crop species. Nat. Genet. 48:201-205.

Meyer, S. E., Stewart, T. E., and Clement, S. 2010. The quick and the deadly: Growth vs virulence in a seed bank pathogen. New Phytol. 187:209-216.

Milgroom, M. G. 2015. Population Biology of Plant Pathogens: Genetics, Ecology, and Evolution. APS Press, St. Paul, MN, U.S.A.

Mirocha, C. J., Gilchrist, D. G., Shier, W. T., Abbas, H. K., Wen, Y., and Vesonder, R. F. 1992. AAL toxins, fumonisins (biology and chemistry) and host-specificity concepts. Mycopathologia 117:47-56.

Möller, M., and Stukenbrock, E. H. 2017. Evolution and genome architecture in fungal plant pathogens. Nat. Rev. Microbiol. 15:771.

Monci, F., Sánchez-Campos, S., Navas-Castillo, J., and Moriones, E. 2002. A natural recombinant between the geminiviruses Tomato yellow leaf curl Sardinia virus and Tomato yellow leaf curl virus exhibits a novel pathogenic phenotype and is becoming prevalent in Spanish populations. Virology 303:317-326.

Moran, N. A., and Jarvik, T. 2010. Lateral transfer of genes from fungi underlies carotenoid production in aphids. Science 328:624-627.

Morris, C. E., Bardin, M., Kinkel, L. L., Moury, B., Nicot, P. C., and Sands, D. C. 2009. Expanding the paradigms of plant pathogen life history and evolution of parasitic fitness beyond agricultural boundaries. PLoS Pathog. 5:e1000693.

Morris, C. E., and Moury, B. 2019. Revisiting the concept of host range of plant pathogens. Annu. Rev. Phytopathol. 57:63-90.

Muñoz-Barrios, A., Sopeña-Torres, S., Ramos, B., López, G., Del Hierro, I., Díaz-González, S., González-Melendi, P., Mélida, H., FernándezCalleja, V., Mixão, V., Martín-Dacal, M., Marcet-Houben, M., Gabaldón, T., Sacristán, S., and Molina, A. 2020. Differential expression of fungal genes determines the lifestyle of Plectosphaerella strains during Arabidopsis thaliana colonization. Mol. Plant-Microbe Interact. 33:1299-1314.

Newberry, E. A., Ebrahim, M., Timilsina, S., Zlatkovi, N., Obradovi A., Bull, C. T., Goss, E. M., Huguet-Tapia, J. C., Paret, M. L., Jones, J. B., and Potnis, N. 2019. Inference of convergent gene acquisition among Pseudomonas syringae strains isolated from watermelon, cantaloupe, and squash. Front. Microbiol. 10:270.

Nottensteiner, M., Zechmann, B., McCollum, C., and Hückelhoven, R. 2018. A barley powdery mildew fungus non-autonomous retrotransposon encodes a peptide that supports penetration success on barley. J. Exp. Bot. 69:3745-3758.

Obasa, K., White, F. F., Fellers, J., Kennelly, M., Liu, S., Katz, B., Tomich, J., Moore, D., Shinogle, H., and Kelley, K. 2017. A dimorphic and virulence-enhancing endosymbiont bacterium discovered in Rhizoctonia solani. Phytobiomes J. 1:14-23.

Pagán, I., and García-Arenal, F. 2019. Population Genomics of Plant Viruses. Pages 233-265 in: Population Genomics: Microorganisms. M. F. Polz and O. P. Rajora, eds. Springer International Publishing, Cham, Switzerland.

Pagán, I., Montes, N., Milgroom, M. G., and García-Arenal, F. 2014. Vertical transmission selects for reduced virulence in a plant virus and for increased resistance in the host. PLoS Pathog. 10:e1004293.

Panstruga, R., and Moscou, M. J. 2020. What is the molecular basis of nonhost resistance? Mol. Plant-Microbe Interact. 33:1253-1264.

Pariaud, B., Ravigné, V., Halkett, F., Goyeau, H., Carlier, J., and Lannou, C. 2009. Aggressiveness and its role in the adaptation of plant pathogens. Plant Pathol. 58:409-424.

Park, R. F., and Wellings, C. R. 2012. Somatic hybridization in the Uredinales. Annu. Rev. Phytopathol. 50:219-239.

Paszkowski, U. 2006. Mutualism and parasitism: The yin and yang of plant symbioses. Curr. Opin. Plant Biol. 9:364-370.

Petit-Houdenot, Y., and Fudal, I. 2017. Complex interactions between fungal avirulence genes and their corresponding plant resistance genes and consequences for disease resistance management. Front. Plant Sci. 8:1072.
Raffaele, S., Win, J., Cano, L. M., and Kamoun, S. 2010. Analyses of genome architecture and gene expression reveal novel candidate virulence factors in the secretome of Phytophthora infestans. BMC Genomics 11:637.

Ravensdale, M., Bernoux, M., Ve, T., Kobe, B., Thrall, P. H., Ellis, J. G., and Dodds, P. N. 2012. Intramolecular interaction influences binding of the Flax L5 and L6 resistance proteins to their AvrL567 ligands. PLoS Pathog. 8:e1003004.

Remold, S. 2012. Understanding specialism when the jack of all trades can be the master of all. P. Roy. Soc. B-Biol. Sci. 279:4861-4869.

Richards, T. A., Soanes, D. M., Jones, M. D. M., Vasieva, O., Leonard, G., Paszkiewicz, K., Foster, P. G., Hall, N., and Talbot, N. J. 2011. Horizontal gene transfer facilitated the evolution of plant parasitic mechanisms in the oomycetes. Proc. Natl. Acad. Sci. U.S.A. 108: 15258-15263.

Robaglia, C., and Caranta, C. 2006. Translation initiation factors: A weak link in plant RNA virus infection. Trends Plant Sci. 11:40-45.

Rohmer, L., Guttman, D. S., and Dangl, J. L. 2004. Diverse evolutionary mechanisms shape the type III effector virulence factor repertoire in the plant pathogen Pseudomonas syringae. Genetics 167:1341-1360.

Roossinck, M. J. 2005. Symbiosis versus competition in plant virus evolution. Nat. Rev. Microbiol. 3:917-924.

Rouxel, T., and Balesdent, M.-H. 2017. Life, death and rebirth of avirulence effectors in a fungal pathogen of Brassica crops, Leptosphaeria maculans. New Phytol. 214:526-532.

Rouxel, T., Grandaubert, J., Hane, J. K., Hoede, C., van de Wouw, A. P., Couloux, A., Dominguez, V., Anthouard, V., Bally, P., Bourras, S., Cozijnsen, A. J., Ciuffetti, L. M., Degrave, A., Dilmaghani, A., Duret, L., Fudal, I., Goodwin, S. B., Gout, L., Glaser, N., Linglin, J., Kema, G. H., Lapalu, N., Lawrence, C. B., May, K., Meyer, M., Ollivier, B., Poulain, J., Schoch, C. L., Simon, A., Spatafora, J. W., Stachowiak, A., Turgeon, B. G., Tyler, B. M., Vincent, D., Weissenbach, J., Amselem, J., Quesneville, H., Oliver, R. P., Wincker, P., Balesdent, M. H., and Howlett, B. J. 2011. Effector diversification within compartments of the Leptosphaeria maculans genome affected by repeatinduced point mutations. Nat. Commun. 2:202.

Ruiz, L., Simón, A., García, C., Velasco, L., and Janssen, D. 2018. First natural crossover recombination between two distinct species of the family Closteroviridae leads to the emergence of a new disease. PLoS One 13:e0198228.

Sacco, M. A., Koropacka, K., Grenier, E., Jaubert, M. J., Blanchard, A., Goverse, A., Smant, G., and Moffett, P. 2009. The cyst nematode SPRYSEC protein RBP-1 elicits Gpa2- and RanGAP2-dependent plant cell death. PLoS Pathog. 5:e1000564.

Sacristán, S., Fraile, A., Malpica, J. M., and García-Arenal, F. 2005. An analysis of host adaptation and its relationship with virulence in Cucumber mosaic virus. Phytopathology 95:827-833.

Sacristán, S., and García-Arenal, F. 2008. The evolution of virulence and pathogenicity in plant pathogen populations. Mol. Plant Pathol. 9:369384.

Sanfaçon, H. 2020. Modulation of disease severity by plant positivestrand RNA viruses: The complex interplay of multifunctional viral proteins, subviral RNAs and virus-associated RNAs with plant signaling pathways and defense responses. Adv. Virus Res. 107:87-131.

Schardl, C. L. 1996. Epichloë Species: Fungal symbionts of grasses. Annu. Rev. Phytopathol. 34:109-130.

Schulze-Lefert, P., and Panstruga, R. 2011. A molecular evolutionary concept connecting nonhost resistance, pathogen host range, and pathogen speciation. Trends Plant Sci. 16:117-125.

Schwartz, A. R., Potnis, N., Timilsina, S., Wilson, M., Patané, J., Martins, J., Jr., Minsavage, G. V., Dahlbeck, D., Akhunova, A., Almeida, N., Vallad, G. E., Barak, J. D., White, F. F., Miller, S. A., Ritchie, D., Goss, E., Bart, R. S., Setubal, J. C., Jones, J. B., and Staskawicz, B. J. 2015. Phylogenomics of Xanthomonas field strains infecting pepper and tomato reveals diversity in effector repertoires and identifies determinants of host specificity. Front. Microbiol. 6:535.

Seidl, M. F., and Thomma, B. P. H. J. 2017. Transposable elements direct the coevolution between plants and microbes. Trends Genet. 33:842-851.

Singh, P. K., Mahato, A. K., Jain, P., Rathour, R., Sharma, V., and Sharma, T. R. 2019. Comparative genomics reveals the high copy number variation of a retro transposon in different Magnaporthe isolates. Front. Microbiol. 10:966.

Singh, R. P., Hodson, D. P., Huerta-Espino, J., Jin, Y., Bhavani, S., Njau, P., Herrera-Foessel, S., Singh, P. K., Singh, S., and Govindan, V 2011. The emergence of $\mathrm{Ug} 99$ races of the stem rust fungus is a threat to world wheat production. Annu. Rev. Phytopathol. 49:465-481. 
Smant, G., and Stokkermans, J. P. W. G. Yan, Y. T., de Boer, J. M., Baum, T. J., Wang, X. H., Hussey, R. S., Gommers, F. J., Henrissat, B., Davis, E. L., Helder, J., Schots, A., and Bakker, J. 1998. Endogenous cellulases in animals: Isolation of beta-1,4-endoglucanase genes from two species of plant-parasitic cyst nematodes. Proc. Natl. Acad. Sci. U.S.A. 95:4906-4911.

Snelders, N. C., Kettles, G. J., Rudd, J. J., and Thomma, B. P. H. J. 2018. Plant pathogen effector proteins as manipulators of host microbiomes? Mol. Plant Pathol. 19:257-259.

Soanes, D., and Richards, T. A. 2014. Horizontal gene transfer in eukaryotic plant pathogens. Annu. Rev. Phytopathol. 52:583-614.

Spanu, P. D., Abbott, J. C., Amselem, J., Burgis, T. A., Soanes, D. M., Stüber, K., Ver Loren van Themaat, E., Brown, J. K., Butcher, S. A., Gurr, S. J., Lebrun, M. H., Ridout, C. J., Schulze-Lefert, P., Talbot, N. J., Ahmadinejad, N., Ametz, C., Barton, G. R., Benjdia, M., Bidzinski, P., Bindschedler, L. V., Both, M., Brewer, M. T., Cadle-Davidson, L., CadleDavidson, M. M., Collemare, J., Cramer, R., Frenkel, O., Godfrey, D., Harriman, J., Hoede, C., King, B. C., Klages, S., Kleemann, J., Knoll, D., Koti, P. S., Kreplak, J., López-Ruiz, F. J., Lu, X., Maekawa, T., Mahanil, S., Micali, C., Milgroom, M. G., Montana, G., Noir, S., O'Connell, R. J., Oberhaensli, S., Parlange, F., Pedersen, C., Quesneville, H., Reinhardt, R., Rott, M., Sacristán, S., Schmidt, S. M., Schön, M., Skamnioti, P., Sommer, H., Stephens, A., Takahara, H., Thordal-Christensen, H., Vigouroux, M., Wessling, R., Wicker, T., and Panstruga, R. 2010. Genome expansion and gene loss in powdery mildew fungi reveal tradeoffs in extreme parasitism. Science 330:1543-1546.

Stukenbrock, E. H., Christiansen, F. B., Hansen, T. T., Dutheil, J. Y., and Schierup, M. H. 2012. Fusion of two divergent fungal individuals led to the recent emergence of a unique widespread pathogen species. Proc. Natl. Acad. Sci. U.S.A. 109:10954-10959.

Stukenbrock, E. H., Jørgensen, F. G., Zala, M., Hansen, T. T., McDonald, B. A., and Schierup, M. H. 2010. Whole-genome and chromosome evolution associated with host adaptation and speciation of the wheat pathogen Mycosphaerella graminicola. PLoS Genet. 6:e1001189.

Stukenbrock, E. H., and McDonald, B. A. 2009. Population genetics of fungal and oomycete effectors involved in gene-for-gene interactions. Mol. Plant-Microbe Interact. 22:371-380.

Tanaka, A., Christensen, M. J., Takemoto, D., Park, P., and Scott, B. 2006. Reactive oxygen species play a role in regulating a fungusperennial ryegrass mutualistic interaction. Plant Cell 18:1052-1066.

Teixeira, P. J. P. L., Colaianni, N. R., Fitzpatrick, C. R., and Dangl, J. L. 2019. Beyond pathogens: Microbiota interactions with the plant immune system. Curr. Opin. Microbiol. 49:7-17.

Temporini, E. D., and VanEtten, H. D. 2004. An analysis of the phylogenetic distribution of the pea pathogenicity genes of Nectria haematococca MPVI supports the hypothesis of their origin by horizontal transfer and uncovers a potentially new pathogen of garden pea: Neocosmospora boniensis. Curr. Genet. 46:29-36.

Tenaillon, O., Denamur, E., and Matic, I. 2004. Evolutionary significance of stress-induced mutagenesis in bacteria. Trends Microbiol. 12:264-270.

Thines, M. 2019. An evolutionary framework for host shifts-Jumping ships for survival. New Phytol. 224:605-617.

Thordal-Christensen, H. 2003. Fresh insights into processes of nonhost resistance. Curr. Opin. Plant Biol. 6:351-357.

Thresh, J. M. 1982. Cropping practices and virus spread. Annu. Rev. Phytopathol. 20:193-216.

Timilsina, S., Potnis, N., Newberry, E. A., Liyanapathiranage, P., Iruegas-Bocardo, F., White, F. F., Goss, E. M., and Jones, J. B. 2020. Xanthomonas diversity, virulence and plant-pathogen interactions. Nat. Rev. Microbiol. 18:415-427.

Tollenaere, C., Susi, H., and Laine, A.-L. 2016. Evolutionary and epidemiological implications of multiple infection in plants. Trends Plant Sci. 21:80-90.

Trudgill, D. L., and Blok, V. C. 2001. Apomictic, polyphagous root-knot nematodes: Exceptionally successful and damaging biotrophic root pathogens. Annu. Rev. Phytopathol. 39:53-77.
Tsushima, A., Gan, P., Kumakura, N., Narusaka, M., Takano, Y., Narusaka, Y., and Shirasu, K. 2019. Genomic plasticity mediated by transposable elements in the plant pathogenic fungus Colletotrichum higginsianum. Genome Biol. Evol. 11:1487-1500.

Upson, J. L., Zess, E. K., Białas, A., Wu, C.-H., and Kamoun, S. 2018. The coming of age of EvoMPMI: evolutionary molecular plant-microbe interactions across multiple timescales. Curr. Opin. Plant Biol. 44: 108-116.

Van der Hoorn, R. A. L., De Wit, P. J. G. M., and Joosten, M. H. A. J. 2002. Balancing selection favors guarding resistance proteins. Trends Plant Sci. 7:67-71.

Varsani, A., Lefeuvre, P., Roumagnac, P., and Martin, D. 2018. Notes on recombination and reassortment in multipartite/segmented viruses. Curr. Opin. Virol. 33:156-166.

van der Plank, J. E. 1968. Disease Resistance in Plants. Academic Press, New York.

van der Walt, E., Rybicki, E. P., Varsani, A., Polston, J. E., Billharz, R., Donaldson, L., Monjane, A. L., and Martin, D. P. 2009. Rapid host adaptation by extensive recombination. J. Gen. Virol. 90: 734-746.

Velásquez, A. C., Castroverde, C. D. M., and He, S. Y. 2018. Plantpathogen warfare under changing climate conditions. Curr. Biol. 28:R619-R634.

Weiberg, A., Wang, M., Lin, F.-M., Zhao, H., Zhang, Z., Kaloshian, I., Huang, H.-D., and Jin, H. 2013. Fungal small RNAs suppress plant immunity by hijacking host RNA interference pathways. Science 342:118-123.

Wheeler, D. L., Scott, J., Dung, J. K. S., and Johnson, D. A. 2019. Evidence of a trans-kingdom plant disease complex between a fungus and plant-parasitic nematodes. PLoS One 14:e0211508.

Win, J., Krasileva, K. V., Kamoun, S., Shirasu, K., Staskawicz, B. J., and Banfield, M. J. 2012. Sequence divergent RXLR effectors share a structural fold conserved across plant pathogenic oomycete species. PLoS Pathog. 8:e1002400.

Woolhouse, M. E. J., and Gowtage-Sequeria, S. 2005. Host range and emerging and reemerging pathogens. Emerg. Infect. Dis. 11: 1842-1847.

Yang, L., Ouyang, H.-B., Fang, Z.-G., Zhu, W., Wu, E. J., Luo, G. H., Shang, L. P., and Zhan, J. 2018. Evidence for intragenic recombination and selective sweep in an effector gene of Phytophthora infestans. Evol. Appl. 11:1342-1353.

Yang, Z., Wafula, E. K., Kim, G., Shahid, S., McNeal, J. R., Ralph, P. E., Timilsena, P. R., Yu, W. B., Kelly, E. A., Zhang, H., Person, T. N., Altman, N. S., Axtell, M. J., Westwood, J. H., and dePamphilis, C. W. 2019. Convergent horizontal gene transfer and cross-talk of mobile nucleic acids in parasitic plants. Nat. Plants 5:991-1001.

Yoshida, K., Saitoh, H., Fujisawa, S., Kanzaki, H., Matsumura, H., Yoshida, K., Tosa, Y., Chuma, I., Takano, Y., Win, J., Kamoun, S., and Terauchi, R. 2009. Association genetics reveals three novel avirulence genes from the rice blast fungal pathogen Magnaporthe oryzae. Plant Cell 21:1573-1591.

Yoshida, K., Saunders, D. G. O., Mitsuoka, C., Natsume, S., Kosugi, S., Saitoh, H., Inoue, Y., Chuma, I., Tosa, Y., Cano, L. M., Kamoun, S., and Terauchi, R. 2016. Host specialization of the blast fungus Magnaporthe oryzae is associated with dynamic gain and loss of genes linked to transposable elements. BMC Genomics 17:370.

Zeng, Q., Wang, J., Bertels, F., Giordano, P. R., Chilvers, M. I., Huntley, R. B., Vargas, J. M., Sundin, G. W., Jacobs, J. L., and Yang, C.-H. 2017. Recombination of virulence genes in divergent Acidovorax avenae strains that infect a common host. Mol. Plant-Microbe Interact. 30:813-828.

Zwart, M. P., and Elena, S. F. 2020. Modeling multipartite virus evolution: The genome formula facilitates rapid adaptation to heterogeneous environments. Virus Evol. 6:veaa022. 